\title{
Life Style Guideline of Ginger (Zingiber officinale) as Prophylaxis and Treatment for Coronaviruses (SARS-CoV-2) Infection (COVID-19)
}

Mamoun Magzoub*

Department of Parasitology \& Medical Entomology, Faculty of Medical Laboratory Science, International University of Africa, Khartoum, Sudan

DOI: $10.36348 /$ sjbr.2020.v05i06.006 | Received: 02.06.2020 | Accepted: 19.06 .2020 | Published: 26.06 .2020

*Corresponding author: Mamoun Magzoub

Email: mosmanmm@hotmail.com

\section{Abstract}

Coronaviruses which are enveloped RNA viruses infect human causing acute and chronic diseases also cause severe acute respiratory syndrome coronavirus (SARS-CoV) and common cold. The aim of this review is to concentrate on ginger which has many benefits to human, as the traditional medicine for the prophylaxis and treatment of COVID-19. In spite of spreading of COVID-19 all over the world, the incidence of the disease among Sudanese people still very low, most probably for their daily habit in using ginger as the traditional herbal drink in their life style. I believe that Ginger is the most effective traditional medicine for prophylaxis and treatment of COVID-19 for its properties in improving immune system and fighting corona viruses, more studies should be conducted to prove this thought.

Keywords: Coronaviruses, COVID-19, Ginger, Prophylaxis, Treatment.

Copyright @ 2020: This is an open-access article distributed under the terms of the Creative Commons Attribution license which permits unrestricted use, distribution, and reproduction in any medium for non-commercial use (NonCommercial, or CC-BY-NC) provided the original author and source are credited.

\section{INTRODUCTION}

Coronaviruses which are enveloped singlestranded RNA viruses infect human causing acute and chronic diseases, also cause severe acute respiratory syndrome coronavirus (SARS-CoV2) [1, 2] and common cold and may be about $15-30 \%$ of common colds are caused by coronavirus [3-5]. COVID-19 appeared at the end of 2019, in Wuhan, China [6-8], it spreads quickly to other areas of China and overseas. World Health Organization (WHO) therefore announced the COVID-19 outbreak a Public Health Emergency of International Concern on Jan. $31^{\text {st }} 2020$ and eventually classified it as a pandemic on March $11^{\text {th }}$ 2020 (9). By way of definition, a symptomatic COVID19 case is a case that has developed signs and symptoms compatible with COVID-19 virus infection. Symptomatic transmission refers to transmission from a person while they are experiencing symptoms. It is primarily transmitted from symptomatic people to others who are in close contact through respiratory droplets, by direct contact with infected persons, or by contact with contaminated objects and surfaces [10]. SARS-CoV-2 infection (COVID-19) can be confirmed in the laboratory by performing real-time reversetranscriptase polymerase-chain reaction (RT-PCR) [11], besides, Chest Computed tomography which is highly sensitive and important method for diagnosing COVID19 [12]. Possible treatment for coronavirus is neutralizing antibodies against the spike $(\mathrm{S})$ protein on the surface of SARS-CoV-2 [13], even the RNAdependent RNA polymerase (RdRp, also named nsp12) is the central component of coronaviral replication/transcription machinery and appears to be a primary target for the antiviral drug, remdesivir [14], but no pharmaceutical treatment available [15]. Prevention is done by the impacts of quarantine, cases and contacts isolation, washing hands, using face masks, health education about other protection methods [16].

\section{Ginger (Zingiber Officinale)}

Ginger (Zingiber Officinale) is a plant which used as a spice, food, flavouring agent, and medicine [17]. Ginger is a standard drug and has broad range of medicinal activity [18]. The World Health organization (WHO) considers ginger as anti-emetic, cholagogic and anti inflammatory properties [19]. Ginger possesses multiple biological activities, including antioxidant, anti-inflammatory, antimicrobial, respiratory protective, antinausea, and antiemetic activities [20]. Besides, Ginger can help in the treatment of inflammatory chronic diseases through anti-inflammatory, immunoregulatory and antioxidative mechanisms [21]. A study was carried out using 6 weeks' ginger period by athletes could modulate inflammation and reduce circulating pro-inflammatory cytokine levels (plasma 
interleukin-1 $\beta$ (IL-1 $\beta$ ), interleukin-6 (IL-6) and tumor necrosis factor- $\alpha$ (TNF- $\alpha)$ ) in these athletes, and possibly limiting the chance of infections and reducing the effects of these cytokines concentrations in inducing fatigue-like symptoms [22]. There are considerations for anti-virulence-based strategies for COVID-19 treatments including blocking components of the innate immune system such as IL-6 and inflammasome activation [23]. Ginger has been granted the GRAS status ("Generally Recognized as Safe") by US Food and Drug Administration (FDA) [24]. In spite of spreading of COVID-19 affecting more than seventy countries all over the world [25], the incidence among Sudanese people is still very low; I believe that using ginger as the traditional herbal drink in their life style is the main reason.

\section{DISCUSSION}

Sudan is a huge country with very poor health and medical facilities particularly in diagnosing diseases such as pandemic COVID-19, so using protection methods is the best way to restrict and eradicate this pandemic coronaviruses infection and this is concordance with approach of Federal Ministry of Health of Sudan, for fighting COVID-19. Sudanese people drink tea and coffee with ginger as the local traditional habit also they drink juice of ginger for the same purpose. They drink ginger juice, either hot or warm for the treatment of common cold which may be caused commonly by coronaviruses [3-5]. From my observation that any one drink ginger juice daily cannot catch common cold, and as some cases of common cold are caused by coronavirus (3-5), so drinking ginger is considered one of the effective herbal medicine for protection from COVID-19, even when infection can be done with symptoms and signs, the disease will be very mild and recovery is occurred quickly. Ginger drink is used as follows: 12 grams of ginger (Zingiber Officinale) powder (one table spoon) dissolved in about $250 \mathrm{ml}$ of warm water three times per day daily, established as the one of life style habits for prophylaxis and using double dose for the treatment, immediately used just after appearance of symptoms and signs of the disease. In my opinion ginger is amazing traditional medicine for prophylaxis and treatment of COVID-19 for its properties in improving immune system increasing IgM levels which may lead improving humoral immunity and also against infections [26], and reduces circulating pro-inflammatory cytokine levels (plasma interleukin-1 $\beta$ (IL-1 $\beta$ ), interleukin-6 (IL-6) and tumor necrosis factor- $\alpha$ (TNF- $\alpha)$ ) [22]. Also through its anti-inflammatory, immunoregulatory and antioxidative mechanisms [21].

\section{CONCLUSION}

I think it is very important to drink ginger juice for all people and all ages above two year old nowadays as a part of life style for protection of COVID-19 for its role in improvement of immune system which is needed for protection and treatment of this pandemic COVID-
$19[21,22]$. Is the stimulation of the immune system caused by ginger reducing susceptibility to COVID-19? To prove this, a study should be carried out for the role of ginger in prophylaxis and treatment of coronaviruses infection as follows: three groups of people with different ages should be screened for COVID-19 by Real Time - Polymerase chain Reaction (RT-PCR). The first group should be negative of COVID-19, the second could be positive but there is no symptoms and signs of the disease, and the last group could be positive for the disease and all subjects have symptoms and signs of COVID 19. The first and second group can take ginger as the drink three times daily for 4 weeks (12 grams of ginger (Zingiber Officinale) powder (one table spoon)), and the last one should take double dose of ginger. All groups should be screened for COVID-19 by RT-PCR, after two weeks and then after two weeks later. So, I think in the absence of vaccine of COVID-19, if this study is conducted, then it can offer one hope towards victory over this disease.

Competing interests: None declared.

\section{ACKNOWLEDGEMENTS}

The author would like to thank Dr. Hisham Magzoub M. Osman, Dubai, UAE, Dr. Israa Osman E. Elshampaty, Dammam, KSA and Mr. Mosab Nouraldein Mohammed Hamad, Head of research unit Banoon fertility center, Khartoum, Sudan.

\section{REFERENCES}

1. Weiss, S. R., \& Leibowitz, J. L. (2011). Coronavirus Pathogenesis. Advances in Virus Research, 81:85-164.

2. Adhikari, S. P., Meng, S., Wu, Y. J., Mao, Y. P., Ye, R. X., Wang, Q. Z., ... \& Zhou, H. (2020). Epidemiology, causes, clinical manifestation and diagnosis, prevention and control of coronavirus disease (COVID-19) during the early outbreak period: a scoping review. Infectious diseases of poverty, 9(1), 1-12.

3. Syed, A. (2020). Coronavirus: A Mini-Review. Int J Curr Res Med Sci. 6(1):8-10.

4. Paules, C. I., Marston, H. D., \& Fauci, A. S. (2020). Coronavirus Infections-More Than Just the Common Cold. JAMA, 323(8):707-708.

5. Mesel-Lemoine, M., Millet, J., Vidalain, P., Law, H., Vabret, A., \& Lorin, V. (2012). A Human Coronavirus Responsible for the Common Cold Massively Kills Dendritic Cells but Not Monocytes. Journal of Virology, 86(14): $7577-$ 7587.

6. Huang, C., Wang, Y., Li, X., Ren, L., Zhao, J., \& Hu, Y. (2020). Clinical features of patients infected with 2019 novel coronavirus in Wuhan, China. Lancet, 395:497-506.

7. Chen, N., Zhou, M., Dong, X., Qu, J., Gong, F., Han, Y., ... \& Yu, T. (2020). Epidemiological and clinical characteristics of 99 cases of 2019 novel coronavirus pneumonia in Wuhan, China: a 
descriptive study. The Lancet, 395(10223), 507513.

8. Wang, D., Hu, B., Hu, C., Zhu, F., Liu, X., Zhang, J., ... \& Zhao, Y. (2020). Clinical characteristics of 138 hospitalized patients with 2019 novel coronavirus-infected pneumonia in Wuhan, China. Jama, 323(11), 1061-1069.

9. Maier, B. F., \& Brockmann, D. (2020). Effective containment explains subexponential growth in recent confirmed COVID-19 cases in China. Science, 368(6492), 742-746.

10. WHO. (2020). Coronavirus disease 2019 (COVID19) Situation Report -82 .

11. National Health Commission of the People's Republic of China. (2020). Novel coronavirus pneumonia diagnosis and treatment program (6th trial version) (in Chinese). http://www.nhc.gov.cn/xcs/

12. Ai, T., Yang, Z., Hou, H., Zhan, C., Chen, C., Lv, W., ... \& Xia, L. (2020). Correlation of chest CT and RT-PCR testing in coronavirus disease 2019 (COVID-19) in China: a report of 1014 cases. Radiology, 200642.

13. Awadasseid, A., Wu, Y., Tanaka, Y., \& Zhang, W. (2020). Initial success in the identification and management of the coronavirus disease 2019 (COVID-19) indicates human-to-human transmission in Wuhan, China. International Journal of Biological Sciences, 16(11), 1846-1860.

14. Gao, Y., Yan, L., Huang, Y., Liu, F., Zhao, Y., Cao, L., ... \& Ge, J. (2020). Structure of the RNAdependent RNA polymerase from COVID-19 virus. Science, 368(6492), 779-782.

15. Kissler, S. M., Tedijanto, C., Goldstein, E., \& Yonatan, H. Grad, and Marc Lipsitch. (2020). 'Projecting the Transmission Dynamics of SARSCoV-2 through the Postpandemic Period'. Science.

16. Layne, S. P., Hyman, J. M., \& David, M. M. (2020). New coronavirus outbreak: Framing questions for pandemic prevention. Sci Transl Med. 12, eabb1469-72.

17. Sharma, Y. (2017). Ginger (Zingiber officinale)-An elixir of life a review. The Pharma Innovation Journal, 6(10):22-27.
18. Bhandari, R., \& Sethiya, J. P. (2018). A Pharmacological Investigation of Zingiber Officinale. International Journal of Research \& Review, 5(10): 465-469.

19. WHO. (2018). WHO Monographs on Selected Medicinal Plants-Volume 1. WHO Essential Medicines and Health Products Information Portal; WHO: Geneva, Switzerland.

20. Mao, Q. Q., Xu, X. Y., Cao, S. Y., Gan, R. Y., Corke, H., \& Li, H. B. (2019). Bioactive compounds and bioactivities of ginger (Zingiber officinale Roscoe). Foods, 8(6), 185.

21. Aryaeian, N., \& Tavakkoli, H. (2015). Ginger and its effects on inflammatory diseases. Adv Food Technol Nutr Sci Open J, 1(4), 97-101.

22. Zehsaz, F., Farhangi, N., \& Mirheidari, L. (2014). The effect of Zingiber officinale $\mathrm{R}$. rhizomes (ginger) on plasma pro-inflammatory cytokine levels in well-trained male endurance runners. Central-European Journal of Immunology, 39(2), 174-180.

23. Ayres, J. S. (2020). Surviving COVID-19: A disease tolerance perspective.

24. US Food and Drug Administration. (2019). CFRCode of Federal Regulations, Title 21-Food and Drugs, Chapter I-Food and Drug Administration, Subchapter B-Food for Human Consumption (continued), Part 182-Substances Generally Recognized as Safe, Subpart A-General Provisions: Sec. 182.20. Available Online: https://www.ecfr.gov/cgi-bin/text idx?SID=dfc2dae5c6f384d423719ba6d29c7c1b\& $\mathrm{mc}=$ true $\&$ node $=\mathrm{se} 21.3 .182 \_120 \& \mathrm{rgn}=\operatorname{div} 8$ (Accessed on 28 January 2019).

25. Ge, H., Wang, X., Yuan, X., Xiao, G., Wang, C., Deng, T., ... \& Xiao, X. (2020). The epidemiology and clinical information about COVID19. European Journal of Clinical Microbiology \& Infectious Diseases, 1.

26. Mahassni, S. H., \& Bukhari, O. A. (2019). Beneficial effects of an aqueous ginger extract on the immune system cells and antibodies, hematology, and thyroid hormones in male smokers and non-smokers. Journal of Nutrition \& Intermediary Metabolism, 15, 10-17. 